\title{
LINGUISTICS
}

UDC 81'373.45

DOI: $10.17223 / 24109266 / 8 / 1$

\section{SEMANTICS TRANSFORMATION IN ANGLO-AMERICAN LOANWORDS IN THE MODERN RUSSIAN LANGUAGE}

\author{
Yu.M. Alyunina, P.J. Mitchell \\ ${ }^{1}$ Tomsk State University (Tomsk, Russian Federation) \\ ${ }^{2}$ Tambov State University (Tambov, Russian Federation) \\ E-mail: alyunina.y@mail.ru; peter_mitchell@mail.ru
}

\begin{abstract}
This paper presents the result of a research made on the material of modern Anglo-American loanwords and their semantic transformation in Russian. The analyzed units were classified into four groups in Russian as a recipient language (Literal meaning, Changed meaning, Nominations, Homonyms), which distinguish the typology of loanwords. As the analysis shows, the change in semantics, if any, indicates not only a change of meaning and a change of functional potential, but also gaps in the language-cultural view of the target-language world. Therefore, loanwords may be viewed as fillers of the view, broadening the conceptual and lexical paradigm and the linguistic structure of the recipient language.
\end{abstract}

Keywords: Anglo-American loanwords; semantics; Russian language.

\section{Introduction}

Language as a self-developing system [1] is constantly enriched by new lexical units, which can be formed either inside the linguistic system with its structural units (neologisms, nonce words and potential words) or come from other linguistic systems and are accepted by the society and, as a consequence, by the language of specific socio-cultural concepts (loanwords).

Nowadays the issue of language interpenetration and inter-enrichment is a current area of investigation in modern linguistics marked with a range of studies, where attention is drawn to different types of lexis that become loaned. For instance, V.A. Mytyashina analyzes semiotic and functions of English lexical units typical for German automobile companies German and Russian Internet-sites versions. Y.V. Krilov studies barbarians and so called pseudoloan words and their specifics in advertisement Russian language discourse on the material of widely known brands "nominatives" («номинативов» [2: 84]). 


\section{Classifications}

In our paper we should mention the work by K.A. Balysheva with the most analyzed typology of lexical loans [3]. The classification shown in the study presents the sequence of stages and their assimilation with the recipient language. The words assimilated in the first stage are used to name loan concepts. Here the law of speech resource economy works: to name a new concept or an object we use the most concrete and precise expression ("billboard, dress-code, casting, reality show, reception, talk-show, fastfood" etc. - «билборд, дресс-код, кастинг, реалити-шоу, ресепшн, токuоy, фacm-фyyd» [Ibid.: 69]). The second stage of assimilation by a recipient language differs in terms of a more complicated word-formation structure of loan units, which leads to the word semantics broadening and its emergence in the receptive linguistic structure. The most productive derivation type is suffixation ("brand, VIP, glamour, distribution $<\ldots>$ image making, corporativity, creativity, speechwriting, $<\ldots>$, monitoring, PR (with the meaning "to promote"), to promote" - «брэ(е)ндовый, виповский (ВИПовский), гламурный, дистрибьюторский <..> имиджмейкерство, корпоративность, креативность, спичрайтерство, < ..> мониторировать, мониторить, пиарить, промоутировать» [Ibid.: 68-69]). The third assimilation stage is characterized by the development of the connotative field and stylistic variation of Anglo-Americanisms in the Russian language, as far as the morphological structure of these words absorbs the suffixes of subjective evaluation («пиарить, пиариться, пиарный, пиаровец, пиарщик» [Ibid.: 71]). As we can see, many studies are devoted to Anglicisms in the modern lexis of different levels. Among the reasons behind such lexical interpenetration the most obvious one is globalization, which is marked in a range of works and can be seen in the following citations: "nominative trend is determined by innovative processes in globalization" [4: 176], "In the context of globalization and broadening language contacts at the turn of the $19-20^{\text {th }}$ centuries the issue of loan words becomes topical" [3: 68].

All the cited authors take into consideration the functional and semantic aspects of the loanwords, however each suggests his/her own classification of Anglicisms in the Russian language. This demonstrates that the system's lexical loanwords and linguistic structures are open and dynamic: each vocabulary subgroup has its own typical traits that do not have a common basis. Consequently, the typologies mentioned do not limit the broadening of further possible paradigms with new material.

\section{Methodology}

Our study focuses on the change of semantics in lexical units in the Russian language loaned from the English language and used by modern 
Russian youth in speech. The research material includes 40 Anglicisms and Anglo-Americanisms from two resources: 1. The work of Russian scholar O.V. Symtseva [5]); 2. Personal observations of the English loanwords used in the modern Russian language.

Despite the above statements about the activity of Anglicisms in linguistic systems which are foreign to the English language, the issue of the term "Anglicism" is still open to some extent. What can we call an Anglicism? Is it a whole loanword or a word formed with the use of originally language-recipient units but on the basis of a loan root morpheme? A Russian scholar of the Siberian linguistic school A.I. Diakov suggests the following definition for the discussed term: this is "all language units taken from the English language structure [6: 74] which are divided into such subgroups as "transliteration, transcription, calque, transformation, transplantation and combination" [Ibid.: 73]. The answer to the question stated in the title of this paper is the suffix added by the word to its structure in the recipient language. If the morpheme is calqued, this should be considered an Anglicism. If the suffix is native for the recipient language, this is a derivation resulting in a derived word with an English root.

In this study we propose our own classification. As already mentioned, this paper demonstrates research on the lexical borrowings most widely used among youth in the Russian language and the borrowings' semantic changes.

To analyze the semantics of the lexical units we used the English and Russian Internet resources: Dictionary.com [7], Oxford Learner's Dictionary [8], Cambridge Dictionaries Online [9] and Academic Dictionaries and Encyclopedias [10].

\section{Results}

The chosen words and collocations may be allocated to four groups according to their semantics when used in the Russian language:

Literal meaning (Table 1). The words whose definitions in Russian (R.) coincide with all of the English ones: boy-friend («бойфренд» = to R. «парень»), to copy paste (in R. it is a noun «копипаст» which can form a verb by adding a inflection -ить «копипастить»), cupcake («капкейк» = to $R$. «кекс»), pancake («панкейк» = to R. «блин/оладушек»), discount («дисконт», can form an adjective by adding the suffix $-\mathrm{H}$ and the inflection -ый «дисконтный», = to R. «скидка»), sale («сэйл» = to R. «скидка»), ok (in R. the letters are the same, so it is difficult to say whether we use the Latin or Cyrillic alphabet - «ок/ОК»), online («онлайн» = to R. «на связи»), price list («прайс-лист» = to R. «цены на товар/услуги»), promoter («промоутер» $=$ to R. «рекламный агент»), provider («провайдер» = to R. «оператор связи»), VIP (frequently used as «VIPперсона»), weekend («уикенд» = to $R$. «выходные/отдых»), baby 
(«бэйби» = to R. «ребёнок» или «детка» in the meaning the Russian youth use it), bike («байк»= to R. «мотоцикл»), chart («чарт»= to R. «список песен»), cookie («куки» = to R. «печенье»), e-mail («и-мэйл/мэйл»= to R. «почта/электронная почта»), fashion («фэшн» = to R. «мода»), login («логин», «залогиниться» $=$ to $\mathrm{R}$. «имя/имя пользователя», «зарегистрироваться/войти (в систему/в личный кабинет)»), manager («менеджер» $=$ to R. «управляющий/заведующий/руководитель (отдела)»), print («принт» = to R. «рисунок»), shopping («шоппинг»= to R. «поход по магазинам»), style («стайл» = to R. «стиль»), tutor («тьютор» = to R. «репетитор/классный руководитель»). As we can see, some of these lexical units have Russian equivalents and some of them can be descriptively translated into the Russian language.

Table 1

\begin{tabular}{|l|l|l|l|}
\hline Original unit & \multicolumn{1}{|c|}{ Original meaning } & $\begin{array}{l}\text { Russian spelling and } \\
\text { transliteration }\end{array}$ & Russian meaning \\
\hline Copy paste & $\begin{array}{l}\text { The system supported by most } \\
\text { document editing applications and } \\
\text { most operating systems that allows } \\
\text { you to select a part of the document } \\
\text { and then save it in a temporary } \\
\text { buffer }\end{array}$ & Копипаст - kopipast & $\begin{array}{l}\text { To copy some text } \\
\text { from a computer } \\
\text { document and to } \\
\text { paste it into another } \\
\text { one }\end{array}$ \\
\hline Cupcake & $\begin{array}{l}\text { A small cake, baked in a paper } \\
\text { container shaped like a cup and } \\
\text { often with icing on top }\end{array}$ & Капкейк - kapkeik & Equal \\
\hline
\end{tabular}

Table 2

\begin{tabular}{|c|l|l|l|}
\hline $\begin{array}{c}\text { Original } \\
\text { unit }\end{array}$ & \multicolumn{1}{|c|}{ Original meaning } & $\begin{array}{l}\text { Russian spelling } \\
\text { and transliteration }\end{array}$ & Russian meaning \\
\hline Hot-dog & $\begin{array}{l}\text { 1) a hot sausage served in a long bread } \\
\text { roll; 2) a person, who performs clever } \\
\text { or dangerous tricks while skiing, } \\
\text { snowboarding or surfing. }\end{array}$ & Хот-дог - khot dog & Literal to 1 \\
\hline $\begin{array}{l}\text { Face- } \\
\text { control }\end{array}$ & $\begin{array}{l}\text { From “feis kontrol”, a Russian klub } \\
\text { colloquialism of the English words } \\
\text { "face control”. Your "face” is your } \\
\text { level of wealth, beauty, power, social } \\
\text { standing, and overall desirability [1] }\end{array}$ & $\begin{array}{l}\text { Фейс контроль - } \\
\text { fеуs kontrol” }\end{array}$ & $\begin{array}{l}\text { Original meaning } \\
\text { appeared in Rus- } \\
\text { sian but with the } \\
\text { use of English } \\
\text { phrase }\end{array}$ \\
\hline
\end{tabular}

Changed meaning (Table 2). The words whose definitions in Russian partially coincide with all of the English ones. Here there could be distinguished two subgroups:

(a) Words with more narrow semantics which either can be substituted with Russian lexical units or earlier assimilated borrowings which are not realized as borrowings by native speakers in everyday speech and are commonly understood: goalkeeper («голкипер»= to R. 
«вратарь»), fast food («фастфуд» = to R. «нездоровая/вредная еда»), hamburger («гамбургер» = to R. «бутерброд»), hot dog («хот дог»= to R. «сосиска в тесте»).

(b) Words adopted for use in some particular context in Russian by associations with their original meanings: face-control (door security in night clubs), like (a social network liking of someone's post), party (an adult party with alcohol), performance (a type of a modern art when an actor or a group of actors perform a piece of art), public (an Internet page, usually in social nets, to publish news and pictures which are not necessarily united with one idea).

Nominations (Table 3). There are words with other meanings which are used as titles: city ("Big City" [12], "СМАЙЛcity" [13], "ФудСity" [14] - Tomsk supermarkets), coffee house ("Koфe Хаyз" [15] - Russian and Ukrainian cafe), Russia ("Hawa Russia" [11] - TV comedy series [16]).

Table 3

\begin{tabular}{|l|l|l|l|}
\hline $\begin{array}{c}\text { Original } \\
\text { unit }\end{array}$ & \multicolumn{1}{|c|}{ Original meaning } & $\begin{array}{c}\text { Russian spelling } \\
\text { and transliteration }\end{array}$ & Russian meaning \\
\hline $\begin{array}{l}\text { Coffee } \\
\text { house }\end{array}$ & $\begin{array}{l}\text { 1) a restaurant serving coffee, etc., } \\
\text { especially one of a type popular in } \\
\text { Britain in the 18 } \\
\text { city in Central Europe; 2) a restaurant } \\
\text { serving coffee, etc. where people go to } \\
\text { listen to music, poetry, etc. }\end{array}$ & $\begin{array}{l}\text { Koфe xayc - } \\
\text { kofe khaus }\end{array}$ & $\begin{array}{l}\text { A proper noun for } \\
\text { a cafe Coffee } \\
\text { House [14] }\end{array}$ \\
\hline Russia & $\begin{array}{l}\text { A country in northern Asia and eastern } \\
\text { Europe }\end{array}$ & Pawa - Rasha & $\begin{array}{l}\text { A word from TV } \\
\text { show name called } \\
\text { Nasha Rasha [15] }\end{array}$ \\
\hline
\end{tabular}

Table 4

\begin{tabular}{|l|l|l|l|}
\hline $\begin{array}{c}\text { Original } \\
\text { unit }\end{array}$ & \multicolumn{1}{|c|}{ Original meaning } & $\begin{array}{l}\text { Russian spelling } \\
\text { and transliteration }\end{array}$ & Russian meaning \\
\hline Look & $\begin{array}{l}\text { 1) the act of looking; } \\
\text { 2) a visual search or examination; } \\
\text { 3) the way in which a person or thing } \\
\text { appears to the eye or to the mind; as- } \\
\text { pect; } \\
\text { 4) an expressive glance; } \\
\text { 5) looks: a) general aspect; appearance; } \\
\text { b) attractive, pleasing appearance }\end{array}$ & Лук - lyk & $\begin{array}{l}\text { Equal to 5. } \\
\text { Bow. } \\
\text { Onion }\end{array}$ \\
\hline Boss & $\begin{array}{l}\text { 1) a person who is in charge of other } \\
\text { people at work and tells them what to } \\
\text { do; } \\
\text { 2) (informal) a person who is in charge } \\
\text { of a large organization }\end{array}$ & Босc - boss & $\begin{array}{l}\text { Equal to 1 and 2. } \\
\text { jargon) } \\
\text { Criminal lord } \\
\text { (prison jargon) }\end{array}$ \\
\hline
\end{tabular}

Homonyms (Table 4). Words with homonyms are lexical units, which have homophones in Russian and can cause misunderstanding. Such words 
are usually used by youth and need to be explained or clarified for elder generation: look (лук - 1. уouth slang, meaning appearance, clothing and hair style; 2. singular for Russian onion; 3 singular for Russian bow), boss (1. office jargon, meaning the head of a company or men of weight; 2. prison jargon of Soviet Union, meaning that a criminal was sentenced by Soviet law-court: BOSS - БОСС - был осуждён советским судом).

\section{Conclusion}

As we can see, most of the analyzed words are placed in the first group with Literal meaning, which signifies that a recipient language and culture accept not only a word but also the concept despite the purpose linguistic system has original equivalents or equivalent phrases for the loaned lexical constructions.

Some of the grouped words can be allocated into two or more subgroups simultaneously. Some words or phrases borrowed from English substitute earlier borrowed lexical units and collocations to make their oral or written expression shorter and more precise semantically. For example, "promoter" substitutes «рекламный агент» which consists of the French words "réclame" and Latin "agens". However, loaned words in Russian, as in any other recipient language, cannot be divided into their constituents. In a recipient language, they perform a single unit semantically and structurally.

To sum up, loans appear in a language to fulfill conceptual lacunas in the linguistic picture of the recipient language speakers and enrich both their verbal and material culture.

\section{References}

1. Gural, S.K. (2012). Language as a self-developing system. Tomsk: TSU.

2. Krylov, Y.V. (2013). Anglicisms in Advertisement Nomination. Humanitarian Research. 1. pp. 83-85.

3. Balysheva, K.A. (2009). Anglicisms in Russian Literary Language at the Turn of XX-XXI. Vestnik of Vyatsky State Humanitarian University. 1. pp. 68-72.

4. Mytyashina, V.A. (2012). Anglicisms in Advertisements: Globalization Mark. Vestnik $M G L U$. 9. pp. 169-177.

5. Symtseva, O.V. (2012). The Reasons of Using Anglicisms in Russian Youth Slang. Molodoy Ucheny. 4. pp. 247-250. URL: http://www.moluch.ru/archive/39/4539/ (accessed: 01.09.2016).

6. Diakov, A.I. (2012). Anglicisms: Loan or Derivation. Philological Sciences. Theory and Practice Issues. 5. pp. 72-75.

7. Dictionary Reference. Available from: http://dictionary.reference.com/ (accessed: 01.09.2016).

8. Oxford Leaner's Dictionary. Available from: http://www.oxfordlearnersdictionaries.com/ (accessed: 01.09.2016).

9. Cambridge Dictionary. Available from: http://dictionary.cambridge.org/ru/ (accessed: 01.09.2016). 
10. Academic Dictionary. Available from: http://dic.academic.ru/ (accessed: 01.09.2016).

11. RuTube. Available from: http://rutube.ru/metainfo/tv/30/ (accessed: 01.09.2016).

12. Big City Webpage. Available from: https://ru.foursquare.com (accessed: 01.09.2016).

13. Smile City Webpage. Available from: http://smilecity.tomsk.ru/ (accessed: 01.09.2016).

14. Food City Webpage. Available from: http://foodcity.tomsk.ru/ (accessed: 01.09.2016).

15. Coffee House Web-page. Available from: http://www.coffeehouse.ru/ (accessed: 01.12.2016).

16. Urban Dictionary. Available from: http://ru.urbandictionary.com/define.php?term= face+control (accessed: 01.09.2016).

Resived 02.09.2016.

\section{Information about the authors}

Alyunina Yuliya - master's student, Department of English Philology, Faculty of Foreign Languages, National Research Tomsk State University (Tomsk, Russian Federation). E-mail: alyunina.y@mail.ru

Mitchell Petr - Ed.D., Associate Professor, Department of English Philology, Faculty of Foreign Languages, National Research Tomsk State University; professor, Department of Linguistics and Humanities Education, G.R. Derzhavin Tambov State University (Tambov, Russian Federation). E-mail: peter_mitchell@mail.ru 